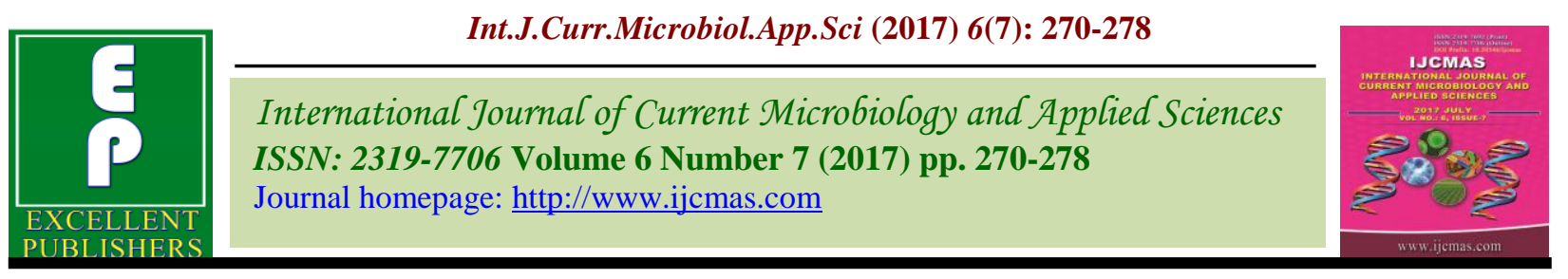

Original Research Article

https://doi.org/10.20546/ijcmas.2017.607.032

\title{
Pollen Quantity, Viability and in vitro Pollen Germination of Longan (Dimocarpus longan Lour.)
}

\author{
Alok Kumar Gupta*, Manvendra Singh, Evening S. Marboh, Vishal Nath, \\ Alemwati Pongener and A.K.D. Anal
}

ICAR-National Research Centre on Litchi, Muzaffarpur-842002 (Bihar), India

*Corresponding author

\begin{tabular}{|c|c|}
\hline & $A B S T R A C T$ \\
\hline & \multirow{8}{*}{$\begin{array}{l}\text { Dimocarpus longan Lour. is an evergreen fruit tree species of Sapindaceae family grown } \\
\text { in subtropical region. Short flowering period coupled with narrow genetic base are the } \\
\text { major constraints in longan genetic improvement. Pollens are known to directly influence } \\
\text { reproductive success and genetic structure of the plant population. In this study, we } \\
\text { compared the pollen quantity, viability and in vitro pollen germination of M1 and } \mathrm{M} 2 \text { type } \\
\text { flowers of nine longan genotypes. Acetocarmine, } 2,3 \text {, 5-triphenyl tetrazolium chloride, } 2 \text {, } \\
5 \text {-diphenyl monotetrazolium bromide and aniline blue-lectophenol staining methods were } \\
\text { used for pollen viability assessment while different concentrations of sucrose, boric acid } \\
\left(\mathrm{H}_{3} \mathrm{BO}_{3}\right) \text { and agar were used for in vitro pollen germination test through hanging drop } \\
\text { technique. Pollen tube growth was evaluated by incubating the media containing pollen at } \\
\text { different temperature and duration. Highest pollen quantity per anther (5278) was observed } \\
\text { in } \mathrm{M} 2 \text { flower of Lgc- } 06 \text {. Acetocarmine ( } 2.0 \% \text { ) showed best results for pollen viability } \\
(94.37 \%) \text { in M } 2 \text { pollen of Lgc- } 06 \text {. Germination media containing } 15 \% \text { sucrose }+100 \\
\text { ppm Boric acid }+0.5 \% \text { agar showed promising results for pollen germination ( } 80.33 \% \text { ). } \\
\text { Highest germination rate ( } 83.66 \%) \text { and maximum pollen tube growth was observed at } \\
30^{\circ} \mathrm{C} \text { for } 24 \text { hours. Overall, pollen from } \mathrm{M} 2 \text { flower had significantly higher pollen } \\
\text { quantity, viability and in vitro pollen germination percentage compared to pollen from M1 } \\
\text { flower. }\end{array}$} \\
\hline Keywords & \\
\hline Longan, & \\
\hline Pollen, & \\
\hline & \\
\hline Article Info & \\
\hline $\begin{array}{l}\text { Accepted: } \\
\text { 04 June } 2017 \\
\text { Available Online: } \\
\text { 10 July } 2017\end{array}$ & \\
\hline & \\
\hline
\end{tabular}

\section{Introduction}

The genus Dimocarpus contained six species (Leenhouts, 1971) out of which five species (Dimocarpus longan, Dimocarpus dentatus, Dimocarpus gardneri, Dimocarpus foveolatus, and Dimocarpus fumatus) exists in Asian countries stretching from India to eastern Malaysia and one (Dimocarpus australianus) in Australia. Dimocarpus longan, usually known as longan is the most commonly cultivated among these species (Pham et al., 2015). Major producers of longan fruit are China, Vietnam, Thailand and it's global production reached more than 2500 million tons (FAO, 2011).

Compound dichasia inflorescences occurred in Longan with duodichogamy condition, i.e. three stages of flowers, blooming simultaneously after each other, with different degree of overlapping among them depending upon genotypes and climatic condition. Flower of the first stage is staminate (pistil nonfunctional) flowers (M1), followed by a second stage of pistillate (stamens non- 
functional) flower (F) and third stage of functionally male hermaphrodite flowers (M2) (Davenport and Stern, 2005; Paull and Duarte, 2011; Pham et al., 2015). Pollination is most effective between 08.00 - 14.00 hours which is performed by various insects, mainly honeybees (Pham et al., 2013). Hence synchronization of male and female flowering is an essential prerequisite for good longan production. However, in longan certain genotypes have been reported to contain unfavorable or sterile pollen or pollen with low germination percentage (Du et al., 2006; Koyuncu and Tosun, 2005; Nikoli'c and Milatovi', 2010; Sharafi, 2011; Calic et al., 2013). Therefore, study of pollen characteristics in different genotypes is important for genetics, pollen-pistil interaction, incompatibility and fertility studies, breeding and crop improvement program (Shivanna and Rangaswamy, 1992).

Pollen physiological condition can be assessed by different staining techniques. Pollen viability test is an easy and fastest method to assess pollen quality but they tend to overestimate the pollen viability and true germination rate of pollen grains (Gaaliche et al., 2013). Accuracy of different viability test varies with species or cultivars (RodriguezRiano and Dafni, 2000). In vitro pollen germination test is a very effective and convenient method to study the applied aspects of pollen biology (Kristen and Kappler, 1990; Grover et al., 2016). Viability and germination test of pollens have been reported in litchi and other several sapindaceous plant species. Literature survey revealed that pollen quantity, viability and in vitro pollen tube growth varied significantly among species, cultivar, and the methods followed. Knowledge on the behavior and characteristics of pollen for a specific genotypes or cultivars is important for crop improvement programs. Perusal of literature reveals a great dearth of information on the aspect of pollen performance in longan. Therefore, the present study was conducted to investigate the pollen quantity, viability and in vitro pollen germination of different longan genotypes.

\section{Materials and Methods}

\section{Study site}

The study was conducted on nine longan genotypes (Lgc-01 to Lgc-09) at Indian Council of Agricultural Research-National Research Centre on Litchi, Muzaffarpur, Bihar, India. The experimental materials consists of 8 to 10 years old longan genotypes. Healthy trees free from diseases and pests were selected for pollen study.

\section{Pollen collection and pollen quantity}

Longan consists of three types of flower viz., staminate (M1), pistillate (F) and functionally male hermaphrodite (M2) flowers which opens in succession one after the other. Fifty anthers each were collected from M1 and M2 flower for each genotype before anthers dehiscence, placed in $2 \mathrm{ml}$ centrifugal tubes followed by drying at $35^{\circ} \mathrm{C}$ under hot air oven for $24 \mathrm{~h}$. The centrifuge tubes were vibrated for cracking the anthers for release the pollen from the pollen sac. One $\mathrm{ml}$ double distilled water was added in the tube and then vortexed for $5 \mathrm{~min}$ to prepare suspension of pollen in water. Pollen quantity was evaluated through the blood count method (Wang et al., 2015) by placing small drop of the suspension in a haemocytometer (Neubauer improved MARIENFELD, Germany) and the quantity of pollen was determined under a Nikon eclipse 50 i microscope (Japan). Pollen grains were situated within a large square $(1.0 \mathrm{~mm} \times$ $1.0 \mathrm{~mm} \times 0.1 \mathrm{~mm}$ in size with 400 small squares) was counted. The pollen quantity per anther was calculated as follows: 
The quantity of pollen/one anther $=(2 \times$ $\left.\mathrm{n} / 10^{-4}\right) / 50$

Where 2 represents $2 \mathrm{ml}$ of suspension, $\mathrm{n}$ represents the mean number of pollen in the large square, $10^{-4}$ represents the volume of the large square, and 50 represents the number of anthers.

\section{Pollen viability test}

Pollen viability was assessed by different staining methods which includes (i) 2.0\% acetocarmine solution (ii) $1.0 \% 2,3,5$ triphenyl tetrazolium chloride (TTC) solution, (iii) 2, 5-diphenyl monotetrazolium bromide (MTT) (Kearns and Inouye, 1993; Abdelgadir et al., 2012; Rodriguez-Riano and Dafni, 2000) and (iv) Aniline blue-lactophenol staining solution (Sheffield et al., 2005; Abdelgadir et al., 2012; Pham et al., 2015). Pollen was viewed under Nikon eclipse $50 \mathrm{i}$ Microscope (Japan) and in each field of view, hundred pollens were counted in each staining procedure for complete viability test. Viable pollen grains, which stained, were distinguished from unstained non-viable grains.

\section{In vitro pollen germination}

Anthers from M1 and M2 flowers of the nine genotype of longan were collected randomly after flower blooming and before anther dehiscence. The collected flowers were placed on Petri dish for one hour at room temperature. Anthers were separate from flowers and left to dry for 3-4 hours. Different concentrations of sucrose, boric acid $\left(\mathrm{H}_{3} \mathrm{BO}_{3}\right)$ and agar were tested for optimization of in vitro pollen germination medium (Taylor and Hepler, 1997). When, the pollen germination media standardized, pollen germination from both stages of each genotype was further studied by incubating the media containing pollens to five temperature regimes $\left(20^{\circ} \mathrm{C}\right.$, $25^{\circ} \mathrm{C}, \quad 30^{\circ} \mathrm{C}, \quad 35^{\circ} \mathrm{C}$ and $\left.40^{\circ} \mathrm{C}\right)$ and $85 \%$ humidity for $24 \mathrm{~h}$ in Petri dishes $(35 \times 10 \mathrm{~mm})$, by spreading the pollen onto the solidified germination medium. The temperature treatments were performed in BOD incubator (NSW, India). In every experiment, pollen germination was evaluated in three petri dishes and observed hundred pollen grains with help of Nikon eclipse 50 i Microscope (Japan). Number of germinated pollen grains and total number of pollen grains were recorded. When pollen tube length growth is double compared to pollen diameter that is pollen is considered germinated. Images were captured after staining the pollen tubes with $2.0 \%$ acetocarmine by Nikon eclipse $50 \mathrm{i}$ Microscope (Japan) (Pham et al., 2015; Wang et al., 2015).

\section{Statistical analysis}

All experiments were performed in triplicate and statistical analysis with JMP software version 12 (SAS, 2016) using Tukey Kramer HSD test for determining significant differences among treatment.

\section{Results and Discussion}

\section{Pollen collection and pollen quantity}

The pollen quantity per anther was assessed in both M1 and M2 flowers. It was observed that the pollen quantity increase with the developmental stage of anther and was similar among the studied genotypes. M1 and M2 flower in the nine longan genotypes (Table 1). The higher quantity of pollen grains was recorded in M2 flower before the anthers dehisce. This result revealed that M2 anthers were the more appropriate for pollen collection.

Longan is a highly cross pollinated crop which depends on the quantity of pollens for successful pollination and higher fruit yield. 
Fresh anthers collected from M1 and M2 flowers at full bloom stage were subjected to present study. In addition, it was also observed that M2 anther contained higher number of pollen than M1 anthers. Similar results were observed in litchi (Wang et al., 2015).

\section{Effect of flower stage on pollen viability}

The pollen viability of different M1 and M2 flowers under different staining methods are shown in table 2. Results revealed that pollen viability differ significantly $(\geq 0.05)$ in different genotypes with respect to stain tests and flower stage (M1 and M2). Acetocarmine $(2 \%)$ treated anthers originating from opened flowers showed maximum viable pollen grains with different size and viability rate. Comparatively, it was also observed that M2 flowers contained more number of viable pollen than M1 flowers in all genotypes (Table 2).

Different type of dyes (acetocarmine, aniline blue, TTC, MTT), which allude the presence of enzymes or cytoplasm, were used to determine the pollen viability (Abdelgadir et al., 2012; Ćalić et al., 2013; Chaudhury et al., 2010; Pham et al., 2015; Wang et al., 2015). In present study, the pollen viability of M1 and M2 flower of longan was assessed and obtained results similar to that reported in litchi (Wang et al., 2015). This can be attributed to the close genetic relationship between longan and litchi. Longan pollen is approximately identical to litchi pollen with pollens being triangular in shape (Pham et al., 2013, 2015). Acetocarmine staining method is most suitable for the pollen viability test with M2 pollen being more viable than M1 pollen.

\section{Optimization of in vitro longan pollen germination medium}

An optimized pollen germination medium has been developed for litchi (Stern and Gazit, 1998; Chaudhary et al., 2010). Owing to paucity of information on the germination media used for longan, the media originally followed for litchi was adopted as a base media for longan in the study.

Fig.1 M1 flower (A), Female flower (B), M2 Flower (C), anther (D), Pollen viability stained by Acetocarmine (2\%) (E), In vitro pollen germination stained by Acetocarmine $(2 \%)(\mathrm{F}, \mathrm{G})$
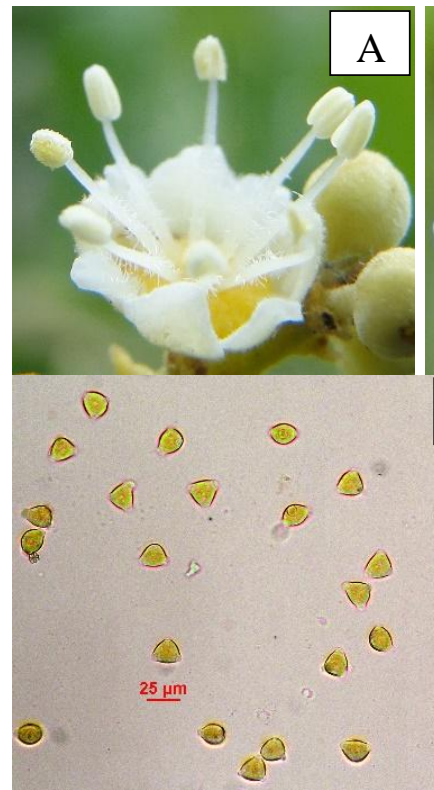
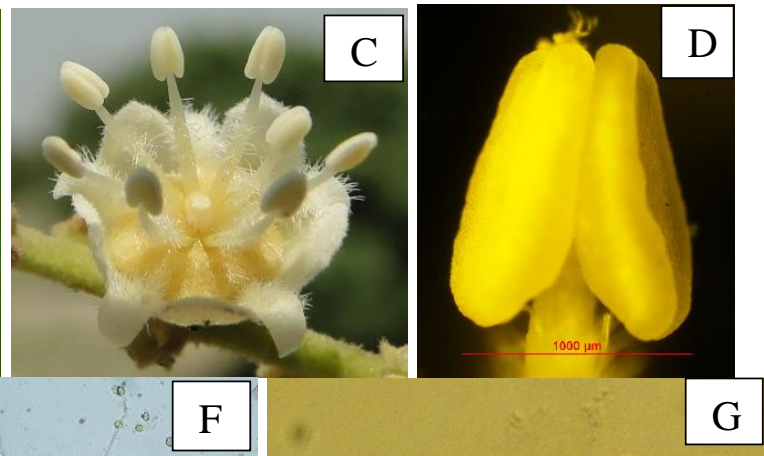
Table.1 Pollen quantity per anther of M1 and M2 flower in nine Longan genotypes

\begin{tabular}{|c|c|c|}
\hline Genotype & M1 & M2 \\
\hline Lgc-01 & $2399.33 \pm 52.05^{\mathrm{c}}$ & $3113.33 \pm 37.29^{\mathrm{d}}$ \\
\hline Lgc-02 & $1990.67 \pm 58.22^{\mathrm{d}}$ & $3409.67 \pm 99.12^{\mathrm{d}}$ \\
\hline Lgc-03 & $2825.33 \pm 73.68^{\mathrm{b}}$ & $3354.33 \pm 74.79^{\mathrm{d}}$ \\
\hline Lgc-04 & $2417.00 \pm 53.50^{\mathrm{c}}$ & $3768.67 \pm 41.57^{\mathrm{c}}$ \\
\hline Lgc-05 & $2918.67 \pm 39.98^{\mathrm{b}}$ & $3955.00 \pm 78.99^{\mathrm{c}}$ \\
\hline Lgc-06 & $3484.00 \pm 85.78^{\mathrm{a}}$ & $5278.00 \pm 51.15^{\mathrm{a}}$ \\
\hline Lgc-07 & $2290.00 \pm 87.72^{\mathrm{cd}}$ & $3141.67 \pm 79.54^{\mathrm{d}}$ \\
\hline Lgc-08 & $2036.67 \pm 37.12^{\mathrm{d}}$ & $3746.33 \pm 42.74^{\mathrm{c}}$ \\
\hline Lgc-09 & $2979.00 \pm 89.76^{\mathrm{b}}$ & $4599.33 \pm 13.83^{\mathrm{b}}$ \\
\hline
\end{tabular}

Table.2 Pollen viability of M1 and M2 pollen of different Longan genotypes

\begin{tabular}{|c|c|c|c|c|c|c|c|c|}
\hline \multirow[t]{2}{*}{ Genotype } & \multicolumn{2}{|c|}{ Aniline blue } & \multicolumn{2}{|c|}{ TTC } & \multicolumn{2}{|c|}{ MTT } & \multicolumn{2}{|c|}{ Acetocarmine } \\
\hline & M1 & M2 & M1 & M2 & M1 & M2 & M1 & M2 \\
\hline Lgc-01 & $58.41 \pm 1.11^{\mathrm{d}}$ & $68.48 \pm 0.75^{\mathrm{d}}$ & $55.96 \pm 0.63^{d}$ & $65.44 \pm 0.55^{\mathrm{e}}$ & $61.72 \pm 0.90^{\mathrm{e}}$ & $75.05 \pm 0.58^{d}$ & $82.66 \pm 0.41^{b c}$ & $89.78 \pm 0.19^{\mathrm{ab}}$ \\
\hline Lgc-02 & $62.93 \pm 0.62^{c}$ & $76.98 \pm 0.78^{b c}$ & $58.78 \pm 0.35^{\mathrm{d}}$ & $67.31 \pm 1.21^{\mathrm{e}}$ & $64.65 \pm 0.89^{\mathrm{de}}$ & $76.36 \pm 1.24^{\mathrm{d}}$ & $86.05 \pm 0.73^{b}$ & $88.82 \pm 0.29^{b}$ \\
\hline Lgc-03 & $71.95 \pm 0.64^{\mathrm{ab}}$ & $84.07 \pm 0.48^{\mathrm{a}}$ & $70.23 \pm 0.60^{\mathrm{ab}}$ & $75.97 \pm 0.31^{\mathrm{cd}}$ & $69.03 \pm 0.57^{\mathrm{cd}}$ & $78.37 \pm 1.25^{\mathrm{cd}}$ & $81.78 \pm 1.00^{\mathrm{c}}$ & $89.57 \pm 1.42^{b}$ \\
\hline Lgc-04 & $68.81 \pm 0.91^{b}$ & $78.35 \pm 1.15^{\mathrm{bc}}$ & $67.44 \pm 0.87^{\mathrm{bc}}$ & $76.24 \pm 0.17^{\mathrm{cd}}$ & $70.65 \pm 1.22^{\mathrm{bc}}$ & $80.33 \pm 1.20^{\mathrm{bcd}}$ & $81.77 \pm 0.89^{c}$ & $90.74 \pm 1.70^{\mathrm{ab}}$ \\
\hline Lgc-05 & $72.31 \pm 0.74^{\mathrm{ab}}$ & $84.30 \pm 1.18^{\mathrm{a}}$ & $70.14 \pm 1.13^{\mathrm{ab}}$ & $79.78 \pm 0.76^{\mathrm{ab}}$ & $64.67 \pm 0.50^{\mathrm{de}}$ & $78.74 \pm 1.36^{\mathrm{cd}}$ & $85.78 \pm 0.37^{b}$ & $89.75 \pm 0.48^{b}$ \\
\hline Lgc-06 & $69.77 \pm 0.82^{b}$ & $75.10 \pm 0.46^{\mathrm{c}}$ & $66.20 \pm 0.85^{c}$ & $73.20 \pm 0.60^{\mathrm{d}}$ & $71.48 \pm 1.32^{b c}$ & $84.92 \pm 0.90^{\mathrm{ab}}$ & $93.43 \pm 0.94^{\mathrm{a}}$ & $94.37 \pm 0.22^{\mathrm{a}}$ \\
\hline Lgc-07 & $70.86 \pm 0.78^{\mathrm{ab}}$ & $76.00 \pm 1.58^{\mathrm{c}}$ & $65.23 \pm 0.55^{\mathrm{c}}$ & $75.72 \pm 0.38^{\mathrm{cd}}$ & $74.83 \pm 0.93^{\mathrm{ab}}$ & $83.66 \pm 0.88^{\mathrm{abc}}$ & $79.91 \pm 0.94^{\mathrm{c}}$ & $88.39 \pm 1.12^{b}$ \\
\hline Lgc-08 & $74.29 \pm 0.60^{\mathrm{a}}$ & $81.33 \pm 0.69^{\mathrm{ab}}$ & $71.20 \pm 0.82^{\mathrm{a}}$ & $80.79 \pm 0.64^{\mathrm{a}}$ & $69.14 \pm 0.70^{\mathrm{cd}}$ & $76.40 \pm 1.14^{\mathrm{d}}$ & $83.23 \pm 0.92^{b c}$ & $90.17 \pm 0.67^{\mathrm{ab}}$ \\
\hline Lgc-09 & $63.16 \pm 0.55^{\mathrm{c}}$ & $78.62 \pm 0.89^{b c}$ & $65.06 \pm 0.68^{c}$ & $77.05 \pm 0.93^{b c}$ & $76.80 \pm 0.91^{\mathrm{a}}$ & $87.71 \pm 0.78^{a}$ & $90.89 \pm 0.97^{\mathrm{a}}$ & $91.90 \pm 0.84^{\mathrm{ab}}$ \\
\hline
\end{tabular}


Table.3 Optimization of in vitro pollen germination media of Longan genotypes

\begin{tabular}{|c|c|c|c|}
\hline Sucrose $(\%)$ & Agar (\%) & Boric acid (ppm) & Pollen germination (\%) \\
\hline \multirow{5}{*}{10} & \multirow{5}{*}{-} & 20 & $1.33 \pm 0.33^{\mathrm{j}}$ \\
\hline & & 40 & $5.66 \pm 0.88^{\mathrm{ij}}$ \\
\hline & & 60 & $12.66 \pm 0.88^{\mathrm{gh}}$ \\
\hline & & 80 & $19.66 \pm 0.88^{\mathrm{ef}}$ \\
\hline & & 100 & $21.66 \pm 0.88^{\mathrm{de}}$ \\
\hline \multirow{5}{*}{15} & \multirow{5}{*}{-} & 20 & $2.00 \pm 0.57^{\mathrm{j}}$ \\
\hline & & 40 & $5.66 \pm 0.88^{i j}$ \\
\hline & & 60 & $11.33 \pm 0.88^{\mathrm{gh}}$ \\
\hline & & 80 & $21.66 \pm 0.88^{\mathrm{de}}$ \\
\hline & & 100 & $26.33 \pm 0.88^{\mathrm{cd}}$ \\
\hline \multirow{5}{*}{15} & \multirow{5}{*}{0.50} & 20 & $11.33 \pm 0.88^{\mathrm{gh}}$ \\
\hline & & 40 & $27.00 \pm 1.15^{\mathrm{c}}$ \\
\hline & & 60 & $31.33 \pm 0.88^{\mathrm{c}}$ \\
\hline & & 80 & $48.33 \pm 1.45^{\mathrm{b}}$ \\
\hline & & 100 & $80.33 \pm 1.45^{\mathrm{a}}$ \\
\hline \multirow{5}{*}{15} & \multirow{5}{*}{1.00} & 20 & $7.66 \pm 0.88^{\mathrm{hi}}$ \\
\hline & & 40 & $11.66 \pm 0.66^{\mathrm{gh}}$ \\
\hline & & 60 & $16.33 \pm 0.88^{\mathrm{fg}}$ \\
\hline & & 80 & $31.33 \pm 0.88^{\mathrm{c}}$ \\
\hline & & 100 & $47.33 \pm 1.45^{b}$ \\
\hline
\end{tabular}

Table.4 Pollen germination of M1 and M2 Pollen at different temperature. Data was observed after 24 hour incubation

\begin{tabular}{|c|c|c|c|c|c|c|c|c|c|c|}
\hline Temp & \multicolumn{2}{|c|}{20} & \multicolumn{2}{|c|}{25} & \multicolumn{2}{|c|}{30} & \multicolumn{2}{|c|}{35} & \multicolumn{2}{|c|}{40} \\
\hline Genotype & M1 & M2 & M1 & M2 & M1 & M2 & M1 & M2 & M1 & M2 \\
\hline Lgc-1 & $13.00 \pm 1.15^{\mathrm{a}}$ & $17.66 \pm 1.45^{\mathrm{bc}}$ & $22.66 \pm 1.20^{\mathrm{d}}$ & $31.00 \pm 1.00^{\mathrm{d}}$ & $42.66 \pm 1.45^{\mathrm{cd}}$ & $61.00 \pm 1.15^{\mathrm{d}}$ & $32.33 \pm 1.45^{\mathrm{b}}$ & $63.00 \pm 1.15^{b}$ & $25.00 \pm 1.73^{\mathrm{b}}$ & $53.66 \pm 1.45^{\mathrm{abc}}$ \\
\hline Lgc-2 & $13.66 \pm 0.33^{\mathrm{a}}$ & $21.33 \pm 1.45^{\mathrm{b}}$ & $24.33 \pm 1.45^{\mathrm{cd}}$ & $33.33 \pm 1.76^{\mathrm{d}}$ & $39.66 \pm 1.20^{\mathrm{d}}$ & $64.00 \pm 1.73^{\mathrm{d}}$ & $31.33 \pm 0.88^{b}$ & $65.00 \pm 1.52^{\mathrm{ab}}$ & $34.33 \pm 2.40^{\mathrm{a}}$ & $55.66 \pm 2.40^{\mathrm{ab}}$ \\
\hline Lgc-4 & $15.00 \pm 1.73^{\mathrm{a}}$ & $20.33 \pm 1.20^{\mathrm{b}}$ & $25.66 \pm 1.45^{\mathrm{cd}}$ & $40.66 \pm 1.20^{\mathrm{bc}}$ & $42.33 \pm 2.02^{\mathrm{cd}}$ & $68.00 \pm 0.57^{\mathrm{cd}}$ & $35.00 \pm 2.30^{\mathrm{ab}}$ & $54.33 \pm 2.02^{c}$ & $27.00 \pm 1.15^{\mathrm{ab}}$ & $46.66 \pm 1.85^{\mathrm{c}}$ \\
\hline Lgc-5 & $14.00 \pm 1.73^{\mathrm{a}}$ & $21.66 \pm 1.33^{b}$ & $31.00 \pm 1.73^{\mathrm{bc}}$ & $46.33 \pm 0.88^{b}$ & $47.33 \pm 1.20^{\mathrm{bc}}$ & $73.00 \pm 2.08^{b c}$ & $36.33 \pm 1.45^{\mathrm{ab}}$ & $64.00 \pm 1.73^{\mathrm{ab}}$ & $26.66 \pm 1.14^{\mathrm{ab}}$ & $50.66 \pm 0.88^{b c}$ \\
\hline Lgc-6 & $13.66 \pm 1.45^{\mathrm{a}}$ & $28.66 \pm 1.20^{\mathrm{a}}$ & $44.33 \pm 2.18^{\mathrm{a}}$ & $52.66 \pm 0.88^{\mathrm{a}}$ & $56.66 \pm 0.88^{\mathrm{a}}$ & $83.66 \pm 1.20^{\mathrm{a}}$ & $41.66 \pm 1.20^{\mathrm{a}}$ & $72.33 \pm 1.85^{\mathrm{a}}$ & $33.66 \pm 2.02^{\mathrm{a}}$ & $61.33 \pm 1.76^{\mathrm{a}}$ \\
\hline Lgc-7 & $13.33 \pm 1.45^{\mathrm{a}}$ & $20.33 \pm 1.45^{b}$ & $23.66 \pm 1.45^{\mathrm{cd}}$ & $45.00 \pm 1.73^{b}$ & $43.33 \pm 0.88^{\mathrm{cd}}$ & $66.66 \pm 2.02^{\mathrm{cd}}$ & $29.33 \pm 0.88^{b}$ & $45.33 \pm 1.45^{\mathrm{d}}$ & $23.66 \pm 0.88^{b}$ & $34.66 \pm 1.20^{\mathrm{d}}$ \\
\hline Lgc-8 & $14.33 \pm 1.20^{\mathrm{a}}$ & $18.33 \pm 1.20^{\mathrm{bc}}$ & $34.66 \pm 1.85^{b}$ & $44.33 \pm 1.20^{b}$ & $52.66 \pm 2.02^{\mathrm{ab}}$ & $75.66 \pm 1.20^{\mathrm{b}}$ & $33.00 \pm 1.15^{b}$ & $64.33 \pm 1.45^{\mathrm{ab}}$ & $23.00 \pm 1.52^{b}$ & $54.00 \pm 1.52^{\mathrm{abc}}$ \\
\hline Lgc-9 & $10.00 \pm 1.00^{\mathrm{a}}$ & $15.33 \pm 1.45^{\mathrm{bc}}$ & $19.33 \pm 0.88^{\mathrm{d}}$ & $36.33 \pm 1.20^{\mathrm{cd}}$ & $43.66 \pm 1.20^{\mathrm{cd}}$ & $64.66 \pm 1.20^{\mathrm{d}}$ & $34.00 \pm 2.08^{b}$ & $44.00 \pm 2.08^{\mathrm{d}}$ & $25.00 \pm 2.08^{b}$ & $36.00 \pm 1.52^{\mathrm{d}}$ \\
\hline
\end{tabular}


Of the different media used (Table 3), results revealed that germination media containing $15 \%$ sucrose, 100 ppm boric acid $\left(\mathrm{H}_{3} \mathrm{BO}_{3}\right)$ and $0.5 \%$ agar gave the maximum number of germinated pollen grains $(80.33 \%)$ with pollen tubes developing adequate lengths through hanging drop technique. Hence this media was considered most efficient for further in vitro pollen germination study of longan.

\section{Pollen tube growth in vitro in different genotypes and temperature}

Based on the media optimized above, pollen germination of M1 and M2 pollens of the studied genotypes, was further evaluated at five temperatures regimes $\left(20^{\circ} \mathrm{C}, 25^{\circ} \mathrm{C}, 30^{\circ} \mathrm{C}\right.$, $35^{\circ} \mathrm{C}$ and $40^{\circ} \mathrm{C}$ ) and pollen germination rate were evaluated after $24 \mathrm{~h}$ in the in vitro germination medium. As presented in table 4, all genotypes showed good pollen germination at $30^{\circ} \mathrm{C}$ on the optimized medium. Significant difference was observed between M1 and M2 pollen among genotypes at different temperature. However at $10^{\circ} \mathrm{C}$, pollen germination of M1 flower did not differ significantly.

At $25^{\circ} \mathrm{C}$, there was a slight increase in pollen germination compared to $10^{\circ} \mathrm{C}$. Highest pollen germination was observed at $30^{\circ} \mathrm{C}$ in both M1 and M2 pollen of the studied genotypes. In addition, genotype Lgc-06 had highest pollen germination percentage in both M1 (56.66 \%) and M2 (83.66 \%) flowers. Above $35^{\circ} \mathrm{C}$, pollen germination reduced gradually in all the genotypes.

However, germination of M2 pollen from Lgc-01 slightly increased at $35^{\circ} \mathrm{C}$. It can be concluded that in vitro pollen germination percentage from M2 flowers was greater than M1 pollens in all genotypes and the optimum temperature for in vitro longan pollen germination ranged between $30^{\circ} \mathrm{C}$ and $35^{\circ} \mathrm{C}$.
Pollen tube growth varies with genotypes. Mostly pollen grains from different species will germinate when placed in calcium, boron and an osmoticant solution. Modified concentration of solution must be performed in vitro germination in the different species and even among cultivars of the same species, although it provides a controlled in vitro condition for pollen germination (Feijó et al., 1995; Obermeyer and Blatt, 1995; Tylor and Hepler, 1997; Pham et al., 2015). Among them, sucrose plays important role both as nutritive compound and osmoregulation (Pham et al., 2013). In vitro germination media was developed for litchi by changing the concentrations of different salts (Stern and Gazit, 1998; Chaudhury et al., 2010). Optimized medium provides high in vitro pollen germination up to $83 \%$ in longan. In previous published reports, higher in vitro germination rate was observed from M2 pollen compare to M1 pollen in litchi (Stern and Gazit, 1998), although small differences were found in South Africa and other regions (Fivaz et al., 1994).

However, Pham et al., 2015 reported that in vitro pollen germination was slightly higher in M1 than in M2 flowers, while a similar trend was observed for the two types of pollen at the different temperatures. Performance of pollen germination in vitro was low at 10 and $20^{\circ} \mathrm{C}$. Parallel results were observed in litchi (Stern and Gazit, 1998; Wang et al., 2015) and longan (Pham et al., 2015), in which the optimal temperature for in vitro pollen germination was also around $30^{\circ} \mathrm{C}$. Developed in vitro pollen germination protocol can be further used to study in pollen collection and conservation so as to bridge the flowering gap among genotypes temporally and spatially, which in turn will facilitates longan breeding programs (Pham et al., 2015). Differences exist among genotypes in pollen germination at different temperatures i.e. fertilization are possible at different 
temperature. Thus, this could be a helpful technique to selection of genotype for adaptation in different climatic condition (Fig. 1).

In the present study, an efficient and simple protocol for pollen germination test was developed and indicated a differential effect of temperature on pollen germination in longan, depending on the genotype. Determining the pollen quantity, viability and germination potential has great importance for establishing fertilization potential for selecting genotypes. Conserving pollen of the greatest viability and with greatest germination potential is of prime importance for the conservation and adaptation to different agro-climatic condition of this valuable longan tree fruit.

\section{Acknowledgments}

We are grateful to thank the Director of ICAR-National Research Centre for Litchi, Muzaffarpur for supporting this study.

\section{References}

Abdelgadir, H.A., Johnson, S.D. and Van Staden, J. 2012. Pollen viability, pollen germination and pollen tube growth in the biofuel seed crop Jatropha curcas (Euphorbiaceae). South African Journal of Botany. 79: 132-139.

Ćalić, D., Devrnja, N., Kostić, I. and Kostić, M. 2013. Pollen morphology, viability, and germination of Prunus domestica cv. Pozegaca. Scientia Horticulturae. 155: 118-122.

Chaudhury, R., Malik, S.K. and Rajan, S. 2010. An improved pollen collection and cryopreservation method for highly recalcitrant tropical fruit species of mango (Mangifera indica L.) and litchi (Litchi chinensis Sonn.). CryoLetters. 31: 268-278.
Davenport, T.L. and Stern R.A. 2005. Flowering. In: Menzel, C.M., Waite, G.K. (Eds.), Litchi and Longan: Botany, Production and Uses. CABI International, Wallingford, UK, pp. 87113.

Du, Y.H., Zhang, S.L., Jiang, T. and Wu, J. 2006. Characteristics of pollen germination and pollen tube growth of Prunus mume in vitro. Acta Botanica. 26: 1846-1852.

FAO, 2011. Committee on commodity problems intergovernmental group on bananas and tropical fruits Fifth Session Tropical fruits compendium.

Feijó, J.A., Malhó, R. and Obermeyer, G. 1995. Ion dynamics and its possible role during in vitro pollen germination and tube growth. Protoplasma, 187: 155167.

Fivaz, J., Robbertse, P.J. and Gazit, S. 1994. Studies on the Morphology, Viability and Storage of Pollen Grains of Litchi (Litchi chinensis Sonn.), pp. 9-12. In: 6. Yearbook of the South African Litchi Growers' Association.

Gaaliche, B., Majdoub, A., Trad, M. and Mars, M. 2013. Assessment of pollen viability, germination, and tube growth in eight Tunisian caprifig (Ficus carica L.) cultivars. ISRN Agronony, 2013: 14.

Grover, A., Twell, D. and Schleiff, E. 2016. Pollen as a target of environmental changes. Plant Reproduction, 29: 1-2.

Kearns, C.A. and Inouye, D.W. 1993. Techniques for Pollination Biologists. pp. 77-151. In: University Press of Colorado, Niwot, CO.

Koyuncu, F. and Tosun, F. 2005. Evaluation of pollen viability and germinating capacity of some sweet cherry cultivars grown in Isparta, Turkey. In: 5th International Cherry Symposium, 6-10 June, Bursa.

Kristen, U. and Kappler, R. 1990. The pollen 
tube system. In vitro. Protocol, 55: 1-7.

Leenhouts, P.W. 1971. A revision of Dimocarpus (Sapindaceae). Blumea, 19: 113-131.

Nikoli', C.D. and Milatovi', C.D. 2010. Examining self-compatibility in plum (Prunus domestica L.) by fluorescence microscopy. Genetika-Belgrade, 42: 387-396.

Obermeyer, G. and Blatt, M.R. 1995. Electrical properties of intact pollen grains of Lilium longiflorum: characteristics of the non-germination grain. Journal of Experimental Botany, 46: 803-813.

Paull, R.E. and Duarte, O. 2011. Tropical Fruits. pp. 221-251. In: 2nd ed. UK, CAB International, Wallingford.

Pham, V.T., Herrero, M., Hormaza, J.I. 2015. Effect of temperature on pollen germination and pollen tube growth in longan (Dimocarpus longan Lour.). Scientia Horticulturae, 197: 470-475.

Pham, V.T., Tran, M.H., Herrero, M. and Hormaza, J.I. 2013. The reproductive biology of the longan. pp. 1242-1246. In: Proceedings of the 5th National Scientific Conference on Ecology and Biological Resources, Hanoi, 18 October 2013. Agriculture Publishing House, Hanoi, Vietnam,

Rodriguez-Riano, T. and Dafni, A. 2000. A new procedure to asses' pollen viability.
Sexual Plant Reproduction, 12: 241244.

Sharafi, Y. 2011. An investigation on the pollen germination and tube growth in some Prunus persica genotypes and cultivars. African Journal of Microbiology Research, 5: 2003-2007.

Sheffield, C.S., Smith, R.F. and Kevan, P.G. 2005. Perfect syncarpy in apple (Malus $\mathrm{x}$ domestica 'Summerland Mclntosh') and its implications for pollination, seed distribution and fruit production (Rosaceae: Maloideae). Annals of Botany, 95: 583-591.

Shivanna, K.R. and Rangaswamy, N.S. 1992. Pollen biology: a laboratory manual. Springer-Verlag.

Stern, R.A. and Gazit, S. 1998. Pollen Viability in Lychee. Journal of the American Society for Horticultural Science, 123: 41-46.

Taylor, L.P. and Hepler, P.K. 1997. Pollen germination and tube growth. Annual Review of Plant Physiology and Plant Molecular Biology, 48: 461-91.

Wang, L., Wu, J., Chen, J., Fu, D., Zhang, C., Cai, C. and $\mathrm{Ou}$, L. 2015. A simple pollen collection, dehydration, and long-term storage method for litchi (Litchi chinensis Sonn.). Scientia Horticulturae, 188: 78-83.

\section{How to cite this article:}

Alok Kumar Gupta, Manvendra Singh, Evening S. Marboh, Vishal Nath, Alemwati Pongener, and Anal, A.K.D. 2017. Pollen Quantity, Viability and in vitro Pollen Germination of Longan (Dimocarpus longan Lour.). Int.J.Curr.Microbiol.App.Sci. 6(7): 270-278. doi: https://doi.org/10.20546/ijcmas.2017.607.032 